\title{
IL1RN Gene
}

National Cancer Institute

\section{Source}

National Cancer Institute. IL1RN Gene. NCI Thesaurus. Code C98164.

This gene is involved in the inhibition of signaling. 